\title{
Legislative framework of in-house procurement
}

\author{
Anatolijs Krivins \\ Daugavpils University, Daugavpils, Latvia
}

\begin{abstract}
The article "Legislative Framework of In-house Procurement" examines the importance of the concept of the in-house transactions in Public Procurement. The purpose of the work is to analyse the Legislative Framework from the perspective of the principle of free competition. The study of free competition is based on works and the main ideas of the following authors: Adam Smith, Jean-Baptiste Say, David Ricardo, Thomas Robert Malthus, John Stuart Mill, John Maynard Keynes, Friedrich August von Hayek and Milton Friedman. Having done the analysis of the EU directives and regulations concerning In-house Procurement (Directive 2014/24/EU; Directive 2014/25/EU; Directive 2013/34/EU; Case C-107/98, Case C-26/03, Case C-84/03, Case C-295/05, Case C-480/06, Case C-324/07, Case C-573/07, Case C-196/08, Case C182/11 and C183/11), as well as normative regulations of several countries, the author made a conclusion, that In-house Procurement contains considerable threats to the principle of free competition in Public Procurement. In-house Procurement contains considerable threats to the principle of free competition in Public Procurement. The data obtained confirm this hypothesis. The results obtained allow us to develop recommendations for the Legislative Framework of In-house Procurement. The results of the research can be used by procurement theoreticians and practitioners.
\end{abstract}

Key words: legislative framework, in-house procurement, free competition.

\section{Introduction}

The aim of this research is to analyse the Legislative Framework from the perspective of the principle of free competition.

The main pillar of the in-house doctrine is the Treaty on the Functioning of the European Union [1] - Article 345 (ex. Article 295 TEC) prescribes: "The Treaties shall in no way prejudice the rules in Member States governing the system of property ownership." Based on the admissibility of the application of the in-house exception, national courts of the EU member countries emphasize rather wide exception limits. For example, Section 16 of the judgment in the Case No. A420612510 rendered by the Department of Administrative Cases of the Supreme Court of the Republic of Latvia on December 29, 2014, states that in the question whether to pass the provision of services to the market as such or to ensure them on one's own, any public person possesses vast freedom of action based on politically defined goals and considerations that may depend on the level of social orientation of the policy it implements. Thus, the control over such determination and action does not abide by the criteria of rights and thus - the influence of the court [2]. Likewise, the Polish Constitutional Tribunal pointed out that the possibility of introducing in-house contracts envisaged by EU law does not prevent the national legislator from putting in place tendering procedures in order to select economic operators to perform specified public tasks [3]. The task of research is to analyze the concept of the in-house transactions in Public Procurement. The object of research is a Legislative Framework of In-house Procurement. 


\section{Materials and methods}

The methods of the present research were: literature review, discourse analysis, logical, deductive and descriptive methods.

\section{Results}

\subsection{In-house doctrine in the European Union rights}

According to Directive 2014/24/EU [4], a public contract awarded by a contracting authority to a legal person governed by private or public law, shall fall outside the scope of this Directive where all of the established conditions are fulfilled. Equal regulation (Contracts between contracting authorities) is contained also in the Directive 2014/25/EU (see Directive's Subsection 3, Article 28) [5]. The aim of Directive 2013/34/EU is designing and delivering regulation of the highest quality whilst respecting the principles of subsidiarity and proportionality [6].

The abovementioned provisions of the Directives become of particular significance in the context of the feasibility regarding the current criteria of the in-house doctrine. While analysing the abovementioned Directives, several crucial considerations should be taken into account. First, there is considerable legal uncertainty as to how far contracts concluded between entities in the public sector should be covered by public procurement rules. Second, the relevant case-law of the Court of Justice of the European Union is interpreted differently between Member States and even between contracting authorities. In this context the relevant case-law of the Court of Justice of the European Union becomes a game-changing decision for two main reasons: 1) The sole fact that both parties to an agreement are themselves public authorities does not rule out the application of procurement rules; 2) the application of public procurement rules should not interfere with the freedom of public authorities to perform the public service tasks conferred on them by using their own resources, which includes the possibility of cooperation with other public authorities [4].

The Directive 2014/24/EU emphasises several significant nuances. On the one hand, the exemption should not extend to situations where there is direct participation by a private economic operator in the capital of the controlled legal person since, in such circumstances, the award of a public contract without a competitive procedure would provide the private economic operator with a capital participation in the controlled legal person an undue advantage over its competitors. On the other hand, where there is private capital participation in the controlling contracting authority or authorities, this does not preclude the award of public contracts to the controlled legal person, without applying the procedures provided for by this Directive as such participations do not adversely affect competition between private economic operators [4].

The second module of information under study that carries considerable significance for the understanding of the in-house doctrine is judgements by the CJEU. The Court's case-law shows that a call for tenders is not mandatory where a public authority, which is a contracting authority, exercises over the separate entity concerned control similar to that which it exercises over its own departments, provided that that entity carries out the essential part of its activity with the public authority or with other controlling local or regional authorities. A public authority has the possibility of performing the public interest tasks conferred on it by using its own resources, without being obliged to call on outside entities not forming part of its own departments, and that it may do so in cooperation with other public authorities [7,8]. 
In any of these cases, it should be carefully verified whether the local authorities at issue were contriving to circumvent the rules on public procurement. [7] According to settled caselaw, the derogations from the rules intended to ensure the effectiveness of the rights conferred by the Treaty in connection with public works contracts must be interpreted strictly $[9,10]$. Directives on public procurement are, in general, applicable in the case where a contracting authority plans to conclude a contract for pecuniary interest with an entity which is legally distinct from it, whether or not that entity is itself a contracting authority. Likewise, that directive applies both where a contract is awarded for the purposes of fulfilling the task of meeting needs in the general interest and where it is unrelated to that task [11].

However, there is an exception to that general rule. The directives on public procurement are not applicable, even if the contracting party is an entity legally distinct from the contracting authority, where two conditions are met. First, the public authority, which is a contracting authority, must exercise over the distinct entity in question a control which is similar to that which it exercises over its own departments and, secondly, that entity must carry out the essential part of its activities with the local authority or authorities which control it [11-14].

There is another option for a public authority falling within the definition of a 'contracting authority' to avoid the application of that directive. That is a situation in which a public authority performs the tasks conferred on it in the public interest by using its own administrative, technical and other resources, without being obliged to call on outside entities not forming part of its own departments. Since in such case there can be no question of a contract for pecuniary interest concluded with an entity, legally distinct from the contracting authority, there is therefore no need to apply the Community rules in the field of public procurement $[11,15]$. That means that public authorities are not obliged, when performing tasks in the public interest, to turn to the market to obtain the provision of a service. They have the option of choosing between using their own resources or of turning to the market [11].

In order to determine whether a public authority exercises over the other party to the contract a control, similar to that which it exercises over its own departments, it is necessary to take account of not only all the legislative provisions but also the relevant circumstances. That must be a power of decisive influence over both strategic objectives and significant decisions of that entity $[8,11,13,16,17]$.

In this aspect, one should agree with the opinion that is presented in the article "In-house Procurement - How it is Implemented and Applied in Poland", namely: EU law sets some limits on in-house procurement but does not in itself guarantee uniform application of this modality, leaving a great deal of freedom to Member States. Moreover, European Union law does not in itself guarantee uniform application of in-house procurement rules, as it leaves a great deal of freedom in this respect to the Member States. Member States still have the sole power to decide whether to make an exception in their legal systems concerning in-house procurement [3].

For example, on 23 February 1996, Asemfo lodged a complaint against Tragsa for a declaration that Tragsa was abusing its dominant position in the Spanish forestry works, services and projects market. According to Asemfo, Tragsa's special status enabled it to carry out a large number of works at the direct demand of the Administration, in breach of the principles relating to public procurement and to free competition, which eliminates any competition on the Spanish market [18]. The set prejudicial question remains without answer since the Court has held the view that there is no precise information in the order for reference concerning the existence of a dominant position, its unlawful exploitation by Tragsa or the effect of such position on trade between the Member States. 
In any event, it is important to recall that, according to the Court's settled case-law, a call for tenders, under the directives relating to public procurement, is not compulsory, even if the contracting party is an entity legally distinct from the contracting authority, where two conditions are met. First, the public authority which is a contracting authority must exercise over the distinct entity in question a control which is similar to that which it exercises over its own departments and, second, that entity must carry out the essential part of its activities with the local authority or authorities which control it $[12,15,17,19,20]$. The market for possible private candidates from elsewhere in the Community is then correspondingly restricted [21].

In cases, where the relationship between a contracting public authority and an executive service or entity is not governed by the Community rules on public procurement the general provisions of the Treaty $[16,22]$, and in particular the provisions on fundamental freedom of movement and competition, remain applicable. Nevertheless, this can result in substantial sub-markets being removed from the operation of primary and secondary Community law on public procurement [21]. Those risks lie in the fact that the useful effect of the Community directives on public procurement may be seriously undermined or, where those directives are not applicable, serious obstacles may arise to the movement of goods and services between States and to freedom of establishment, and competition between those executive services or publicly controlled entities and private undertakings on the relevant markets may be seriously distorted [21].

Let us review the following example - Judgement of the Court in Case C-573/07 Sea [23]. In this aspect, exceptionally, special circumstances may require events occurring after the date on which the contract in question was awarded to be taken into consideration. Such is the case, in particular when shares in the contracting company, previously wholly owned by the contracting authority, are transferred to a private undertaking shortly after the contract at issue has been awarded to that company by means of an artificial device designed to circumvent the relevant Community rules [20, 23].

It is apparent from the case-law that the award of a public contract to a semi-public company without a call for tenders would interfere with the objective of free and undistorted competition and the principle of equal treatment, in that such a procedure would offer a private undertaking with a capital holding in that company an advantage over its competitors $[15,20,24]$.

In the case C196/08 Acoset, the Advocate General has expressed several crucial comments. Namely, the Advocate General considers that Unlike Commission v Austria [20], in which the Court found that there was an artificial construction comprising several distinct stages and revealed the unlawful nature of the award of a contract to a semi-public company under the guise of an in-house relationship, in the present dispute the issue of competition comes into play and displays unprecedented potential in a procedure in which a measure of economy is evident, for, in a single instrument, a company is incorporated and assigned a task, and the criteria for inclusion of the private industrial participant are adopted. What more can one ask? The difficulty thus arises of determining whether that procedural short-cut complies with the requirements of Community law /.../ An affirmative answer to the question referred for a preliminary ruling is unavoidable given the need for efficient administration, which is an essential requirement, provided that the safeguards deriving from Community law are not disregarded [25].

The answer to the question must therefore be that Directive 93/36 is applicable in the case where a contracting authority, such as a local authority, plans to conclude in writing, with an entity which is formally distinct from it and independent of it in regard to decision-making, a contract for pecuniary interest for the supply of products, whether or not that entity is itself a contracting authority [12]. 
On the basis of the analysis performed it can be stated that the EU member countries have too much freedom in the interpretation of the in-house exception. Furthermore, although the Directives 2014/24/EU and 2014/25/EU, as well as court judicature determine certain inhouse limits, yet the most important decision - to decide in favour of one's own firm or the free market - still remains up to the customer.

The article will continue with the analysis of the risks set by the in-house doctrine, among them questions whether the customers always decently use this freedom of action and if it is really necessary to have this amount of freedom of action.

\subsection{In-house doctrine within the principle of free competition}

In the classical understanding "Free competition" meant absence of grants of exclusive privilege, freedom of trade and freedom of entry into occupations [26]. For example, to Adam Smith, "competition" meant competition unhampered by governmental grants of exclusive privilege - rivalry between two or more independent persons or firms, the competition of sellers, which bids prices down when supply is greater than demand $[26,27]$.

The concept of the free competition traditionally includes liberty to choose one's employment, free competition, free trade, beyond as well as within the frontiers of a single country, free banks, and a competitive rate of interest; and on the negative side it implies resistance to all State intervention wherever the necessity for it cannot be clearly demonstrated [28]. In the opinion of Classical writers, free competition was the sovereign natural law.... It secured cheapness for the consumer, and stimulated progress generally because of the rivalry it aroused among producers [28].

Taking into account the facts mentioned, it is logical to conclude that artificial limitation of competition (also as in-house deals) causes significant risk of rise in the price and hindering the progress. The majority of classical economists emphasize the negative manifestations of the competition restriction. For example, Ricardo - there are several pages of attack on the British colonial monopolies - grants of exclusive privilege such as the British East India Company [29]. John Stuart Mill predicts misallocation of resources in markets where monopoly power prevails $[30,31]$.

Jean-Baptiste Say believed that the love of domination never attains more than a factitious elevation, which is sure to make enemies of all its neighbours [32]. While studying the impact of the in-house doctrine on the principle of the free competition, it is very important to define the compulsory traits of the free competition. According to Lewis Henry Haney, perfectly equal competition is rare, and elements of differential advantage abound on all hands [33]. "Perfectly free competition" implied not only absence of price discrimination, but also a large number of buyers and sellers in each industry [34]. "Free market" implies that at each step of the way, terms of exchanges, or prices, are determined by the voluntary interactions of suppliers and demanders. This market is "free" because choices, at each step, are made freely and voluntarily. The market, then, is not simply an array; it is a highly complex, interacting latticework of exchanges [35].

According to Alfred Marshall, we do not assume that competition is perfect. Perfect competition requires a perfect knowledge of the state of the market [36]. John Bates Clark [37] emphasizes that labour and capital must be absolutely mobile [35]. The free competitive market also rewards and stimulates technological innovation. Does the restriction of competition have its positive aspects? In the philosophical view, a common charge against the free-market society is that it institutes "the law of the jungle," of "dog eats dog," that it spurns human cooperation for competition. Yet the historical development of the world has proven that the peaceful market competition of producers and suppliers is 
a profoundly cooperative process in which everyone benefits and where everyone's living standard flourishes [35].

Though in particular conditions monopolies and protectionism can also ensure particular benefits (Clark saw the advantages that could come from mergers and large firms: a vast corporation that is not a true monopoly may be eminently progressive [38]), yet these probable benefits do not compensate for obvious drawbacks. As it is justly indicated by Alfred Marshall "a man of sound judgment ... will keep a watchful eye on sources of possible competition, direct and indirect" [39], albeit the difficulty does not lie in finding a producer, but in finding a consumer [32].

The in-house question affects not only the aspect of offer, but also that of demand. If services of a particular supplier are used only by the only big customer, such order will hardly be efficient. Already in the $19^{\text {th }}$ century this issue was highlighted by Thomas Robert Malthus: thirty or forty proprietors, with incomes answering to between one thousand and five thousand a year, would create a much more effectual demand for the necessaries, conveniences, and luxuries of life, than a single proprietor possessing a hundred thousand a year [40]. Like in the past landowners had assured the best places in Malthus's banquet through force, and that they could benefit from it without contributing to the growth of the national Wealth [31], also today businessmen who enjoy the in-house privilege, gain advantage without any risk. Here we can quote Mill: "They grow richer, as it were in their sleep, without working, risking or economizing" [41].

While outlining the drawbacks of limiting the free competition, the following points should be mentioned. In the long run, coercion is a negative-sum game that leads to reduced production, saving, and investment; a depleted stock of capital; and reduced productivity and living standards for all, perhaps even for the coercers themselves [35].

The economic freedom (as the freedom to produce, trade and consume any goods and services acquired without the use of force, fraud or theft), that correlates with the highest standard of living, economic growth, income equality, less corruption and less political violence is based on three cornerstones: 1) Rule of law; 2) Private property rights; 3) Freedom of contract. Freedom of contract is the right to choose one's contracting parties and to trade with them on any terms and conditions one sees fit. Contracts permit individuals to create their own enforceable legal rules, adapted to their unique situations [42]. Parties decide whether contracts are profitable or fair, but once a contract is made they are obliged to fulfil its terms, even if they are going to sustain losses by doing so [43]. Government, in every society, is the only lawful system of coercion [35].

Smith believed that any interference with free competition by government is almost certain to be injurious. If profits in one line of business are unduly large, there will be a rush of other businessmen into that field until competition has lowered surpluses [44]. The nature of the market has changed vastly since the 18th century - put into today's language, Smith explicitly recognizes the usefulness of public investment for projects that cannot be undertaken by the private sector - he mentions roads and education as two examples. Smith is against government laws that shelter industry from competition. The great enemy to Adam Smith's system is not so much government per se as monopoly in any form [44].

John Maynard Keynes provided a specific rationale for government's taking a bigger role in the economy and a more general confidence in the ability of government to intervene and manage effectively. However, in1970s that evidence began to accumulate in many countries that Keynes's theories, at least as implemented by Keynes's advocates after his death, might not perpetually yield the favourable outcomes Keynes himself had predicted [45].

Friedrich von Hayek believed that the problem of knowledge defeats central control of economies: where effective competition can be created, it is a better way of guiding individual efforts than any other. It does not deny, but even emphasizes, that, in order that competition 
should work beneficially, a carefully thought-out legal framework is required. And it regards competition as superior not only because it is in most circumstances the most efficient method known, but even more because it is the only method by which our activities can be adjusted to each other without coercive or arbitrary intervention of authority [46]. It is necessary in the first instance that the parties in the market should be free to sell and buy at any price at which they can find a partner to the transaction and that anybody should be free to produce, sell, and buy anything that may be produced or sold at all. And it is essential that the entry into the different trades should be open to all on equal terms and that the law should not tolerate any attempts by individuals or groups to restrict this entry by open or concealed force [46].

Exceptions to the free competition should be admitted where no legal arrangements can create the main condition on which the usefulness of the system of competition and private property depends: namely, that the owner benefits from all the useful services rendered by his property and suffers for all the damages caused to others by its use, [46] where the implementation of that cooperation is governed solely by considerations relating to the public interest and that no private service provider is placed in a position of advantage vis-à-vis its competitors [4].

It is not unusual for a number of public authorities to establish, for the execution of certain public tasks such as sewage treatment, a partnership which is responsible for managing a joint executive service [21]. But the fact that we have to resort to the substitution of direct regulation by authority, where the conditions for the proper working of competition cannot be created, does not prove that we should suppress competition where it can be made function [46]. The only exception is where there is objective justification for such work, such as in the case of natural disasters or similar exceptional circumstances [21].

The role of the State in ensuring the free competition is of extreme significance: 1) to create conditions in which competition will be as effective as possible, to supplement it where it cannot be made effective, to provide the services, 2) an effective competitive system needs an intelligently designed and continuously adjusted legal framework as much as any other. [47] In Milton Friedman's view, if you have a central direction you inevitably have coercion. The only way that has ever been discovered to have a lot of people cooperate together voluntarily is through the free market [48].

The article "In-house providing and (minimum) "effective" public control: Sunset or breaking dawn for purely public (commercial) service providers? (C182 and 183/11)" has analysed statements that are present in the Judgment of the Court of Justice of the EU of 29 November 2012 in Joined Cases C182/11 and C183/11. According to this line of case law, contracting entities can award contracts directly (without a competitive tender) where they exercise over the contractor a control similar to that which they have over their own departments, and the contractor carries out the essential part of its activities with the contracting authorities to which it belongs. In those cases, it is assumed that there is no potential for competition and that the market is not affected by the decision of the contracting authority to retain the activity "in-house" [49].

Particular attention should be paid to Section 31 of the judgment: where the position of a contracting authority within a jointly owned successful tender does not provide it with the slightest possibility of participating in the control of that tender, that would, in effect, open the way to circumvention of the application of the rules of EU law regarding public contracts or service concessions, since a purely formal affiliation to such an entity or to a joint body managing it would exempt the contracting authority from the obligation to initiate a tendering procedure in accordance with the EU rules, even though it would take no part in exercising the 'similar control' over that entity $[22,50]$. 
This risk has not been duly evaluated in the EU Directives. No doubt that the in-house doctrine limits the free competence in any case by attributing the procurement beyond open procedures. This considerably increases the risk of corruption. For instance, in Poland, what has been observed on the market is the tendency for municipal companies to use the privilege created for them in in-house procurement regulations to encroach on a market that is not related to the tasks of their owner and compete with private operators. (One of the practices enabling local authorities to bypass statutory restrictions when contracting their tasks to municipal companies is to set up subsidiaries (or sister companies) of a municipal company) [3]. Undoubtedly, if the contracting authorities want to disengage from the direct management of those services and take the back seat (for example in a board of directors), there is no reason to see why public contractors should be shielded from the competition of private contractors, since both would be offering a commercial relationship to the outsourcing contracting authority and there would be an effective risk of generating relevant distortions of competition [49, 51]. Therefore, in the lack of a sufficiently active involvement, in the absence of an actual organic link between the contracting authority and the "in-house" entity, there is no good reason to exclude the application of the EU public procurement rules [49].

One should agree with the conclusion expressed in the article, yet not only because of the justification provided in the article. Danger lies not in the aspect who governs the supplier with the preferences, but in the restriction of the competition per se. From the business point of view, there is no considerable difference in who the preference is given to - a businessman with the State/municipal capital or a private firm, since in both cases the consequences are the same - the principle of the free competition is deformed. In this aspect the primary issue is not that of control (or formal conformity), but that of expedience.

\section{Conclusions}

1. On the basis of the analysis performed it can be stated that the EU member countries have too much freedom in the interpretation of the in-house exception. Furthermore, although the Directives 2014/24/EU and 2014/25/EU, as well as court judicature determine certain in-house limits, yet the most important decision - to decide in favour of one's own firm or the free market - still remains up to the customer.

2. The in-house exception should be interpreted as narrowly as possible. Otherwise the regulation regarding ensuring of the free competition included in the Directives will carry declarative character only.

3. The in-house doctrine, being in philosophical contradiction with the principle of the free competition, considerably endangers both the concept of the free economy and the free market. No doubt that the in-house deals definitely limit the free competition. The question is only about the fact to what extent this limitation is justifiable and required.

4. The author of the article holds a view that the legal, economical or philosophical necessity for such an exception cannot be justified in standard fields that are widespread in the market - such as construction work, designing services and other. Therefore, EU Directives shall clearly and unmistakably state what particular types of procurement contracts (fields) can enjoy the in-house advantages. Only specific fields should be left on this list of exceptions - for instance, waste management, production of heat energy, water supply, etc.

5. Administrative convenience the customer may gain as the result of an in-house deal (savings on indirect costs in case public procurement is not realized, faster process for concluding a procurement contract, more convenient administration of the concluded contract, etc.) cannot be more important than the free competition and efficient 
use of public funds. Therefore, in fields where competition exists, verification of economic efficiency of the planned procurement contract must be performed as an open procurement procedure where any supplier could participate.

6. The in-house doctrine has considerable impact not only on the free competition, but also on the EU fundamental values regarding economy without borders (since in this way the locals can ensure protectionism), it affects risks of corruption.

\section{References}

[1] Consolidated version of the Treaty on the Functioning of the European Union // Available at: https://eur-lex.europa.eu/legal-content/EN/TXT/ HTML/?uri=CELEX : 12012E /TXT \&from=LV (seen on 05.02.2019)

[2] Available at: http://www.at.gov.lv/downloadlawfile/4425 (seen on 05.02.2019)

[3] W. Hartung, K. Kuzma, In-house Procurement - How it is Implemented and Applied in Poland. European Procurement \& Public Private Partnership Law Review 13(3), 171183 (2018), https : //doi .org/10.21552/epppl/2018/3/4 (seen on 05.02.2019)

[4] Directive 2014/24/EU of the European Parliament and of the Council of 26 February (2014)

[5] Directive 2014/25/EU of the European Parliament and of the Council of 26 February (2014)

[6] Directive 2013/34/EU of the European Parliament and of the Council of 26 June 2013

[7] Judgement of the Court in Case C-480/06 Commission v. Germany, [2009] ECR I-04747

[8] Judgement of the Court in Case C324/07 Coditel Brabant [2008] ECR I0000

[9] Judgement of the Court in Case C-57/94 Commission v Italy [1995] ECR I-1249

[10] Judgement of the Court in Case C-318/94 Commission v Germany [1996] ECR I-1949

[11] Opinion of Advocate General in Case C-480/06 Commission v. Germany

[12] Judgement of the Court in Case C107/98 Teckal [1999] ECR I8121

[13] Judgement of the Court in Case C337/05 Commission v Italy [2008] ECR I0000

[14] Judgement of the Court in Case C-371/05 Commission v. Italy [2008] ECR I-00110

[15] Judgement of the Court in Case C26/03 Stadt Halle and RPL Lochau [2005] ECR I1

[16] Judgement of the Court in Case C458/03 Parking Brixen [2005] ECR I8585

[17] Judgement of the Court in Case C340/04 Carbotermo and Consorzio Alisei [2006] ECR I4137

[18] Judgement of the Court in Case C-295/05 Asemfo [2007] ECR I-2999

[19] Judgement of the Court in Case C-84/03 Commission v Spain [2005] ECR I-139

[20] Judgement of the Court in Case C-29/04 Commission v Austria [2005] ECR I-9705

[21] Opinion of Advocate General in Case C-295/05 Asemfo

[22] Judgement of the Court in Case C231/03 Coname[2005] ECR I-7287

[23] Judgement of the Court in Case C-573/07 Sea [2009] ECR I-8127

[24] Judgement of the Court in Case C-196/08 Acoset [2009] ECRI-9913

[25] Opinion of Advocate General in Case C-196/08 Acoset

[26] Ludwig von Mises Institute, Strictly Confidential: The Private Volker Fund Memos of Murray N. Rothbard (2010). https://mises.org/library/ strictlyconfidential-private-volker-fund-memos-murray-n-rothbard

[27] A. Smith, Wealth of Nations. Modern Library (2000)

[28] C. Gide, C. Rist, A History of Economic Doctrines from the Time of the Physiocrats to the Present Day. Heath (1930) 
[29] D. Ricardo, On the Principles of Political Economy and Taxation. Piero Sraffa (Ed.) Works and Correspondence of David Ricardo, Volume I (Cambridge University Press, 1951)

[30] J.S. Mill, Principles of Political Economy (Appleton, 1901)

[31] E. Trincado Aznar, A turning point in the concept of justice: from Adam Smith to John Stuart Mill. Las Torres de Lucca. Int. J. Political Phil. 1, 75-96 (2012)

[32] J.B. Say, A Treatise on Political Economy. Augustus M Kelly (New York, 1964)

[33] L.H. Haney, History of Economic Thought (Macmillan, 1949)

[34] W.S. Jevons, The Theory of Political Economy, 3rd ed. (Macmillan, 1888)

[35] The Library of Economics and Liberty, Free Market by Murray N. Rothbard (2009). Available at: http://www . econlib.org/library/Enc1/FreeMarket.html (seen on 05.02.2019)

[36] A. Marshall, Principles of Economics, 8th ed. (Macmillan, 1938)

[37] J.B. Clark, The Distribution of Wealth: A Theory of Wages, Interest and Profits (The Macmillan Company, NY, 1908)

[38] J.B. Clark, Essentials of Economic Theory: As Applied to Modern Problems of Industry and Public Policy Macmillan (1907)

[39] A. Marshall, Industry and Trade: A Study of Industrial Technique and Business Organization; and of their Influences on the Conditions of Various Classes and Nations (Macmillan, London, 1919)

[40] T.R. Malthus, On the Progress of Wealth. Reprinted from his Principles in "Studies in Economic Development". Edited by Okun and Richardson, Holt, Rinehart and Winston (1961)

[41] J.S. Mill, The Collected Works of John Stuart Mill, Volume XX - Essays on French History and Historians, ed. John M. Robson, Introduction by John C. Cairns. Toronto, University of Toronto Press, London, Routledge and Kegan Paul (1985)

[42] J.V. Orth. Contract and the Common Law. The State and Freedom of Contract (Stanford University Press, 1998)

[43] D.A. Harper. Foundations of Entrepreneurship and Economic Development. Routledge, 82-88 (1999)

[44] The Lives, Times, and Ideas of the Great Economic Thinkers by Robert L. Heilbroner, 7th ed. (1999)

[45] Available at: https://www.pbs.org/wgbh/commandingheights/shared/ minitext/ess_keynesiantheory.html (seen on 05.02.2019)

[46] The Road to Serfdom: Text and Documents-The Definitive Edition (The Collected Works of F. A. Hayek, Vol. 2 (2007)

[47] J.C. Wood, R.D. Wood, F.A. Hayek: 2nd series (Taylor \& Francis, 2004)

[48] Available at: http://www.pbs.org/wgbh/commandingheights/press_site/ people/friedman_intv.html (seen on 05.02.2019)

[49] In-house providing and (minimum) "effective" public control: Sunset or breaking dawn for purely public (commercial) service providers? (C182 and 183/11) (2012). Available at: http://www.howtocrackanut.com/blog/2012/12/in-house-providing-andminimum. html (seen on 05.02.2019)

[50] Judgement of the Court in Joined Cases C-182/11 and C-183/11, Econord [2012] ECR I-00000

[51] S. Graells, Public Procurement and the EU Competition Rules (Oxford, Hart Publishing, 2011) 